\title{
Controlled Release Tablets of Zileuton by Using Gum Based and Hpmc Polymers
}

\author{
Ayesha Haseena*, Asfia Kauser, Faheem Unnisa Begum, Taiyaba Fatima \\ *Assistant Professor, Shadan Women's College of Pharmacy, \\ Khiartabad, Hyderabad, Department of Pharmaceutics
}

\begin{abstract}
The aim of the present study was to develop Controlled release formulation of Zileuton to maintain constant therapeutic levels of the drug for over 12 hrs. Sodium alginate, Guar gum and HPMC K15M were employed as polymers. Zileuton dose was fixed as $300 \mathrm{mg}$. Polymers were used in the concentration of 100, 200 and $300 \mathrm{mg}$ concentration. All the formulations were passed various physicochemical evaluation parameters and they were found to be within limits. Whereas from the dissolution studies it was evident that the formulation (F6) showed better and desired drug release pattern i.e., $98.86 \%$ in 12 hours. It contains the natural polymer Zileuton as controlled release material. It followed zero order release kinetics mechanism.
\end{abstract}

Keywords: Zileuton, Guar gum, HPMC K15 M, Sodium alginate and controlled release tablets.

\section{Controlled Drug Delivery System}

\section{Introduction}

A controlled release drug delivery system delivers the drug locally or systemically at a predetermined rate for a specified period of time. The goal of such systems is to provide desirable delivery profiles that can achieve therapeutic plasma levels. Drug release is dependent on polymer properties, thus the application of these properties can produce well characterised and reproducible dosage forms.

\section{Advantages of Controlled Drug Delivery System}

1. Reduction in frequency of drug administration.

2. Improved patient compliance.

3. Improvement in bioavailability of some drugs because of spatial control.

\section{Disadvantages Of The Drug Delivery Systems}

1. Retrieval of drug is difficult in case of toxicity, poisoning or hypersensitivity reactions.

2. Reduced potential for dosage adjustment of drugs normally administered in varying strengths.

3. Stability problems.

\section{Classification}

1. Dissolution controlled release

a) Matrix dissolution control

b) Reservoir dissolution control

2. Diffusion controlled release

a) Matrix diffusion control

b) Reservoir diffusion control

3. Dissolution and Diffusion controlled systems

4. Water penetration controlled systems

a) Osmotic controlled release

b) Swelling controlled release

5. Hydrogels

6. Ion exchange resins

7. $\mathrm{pH}$ independent formulation

8. chemically controlled system

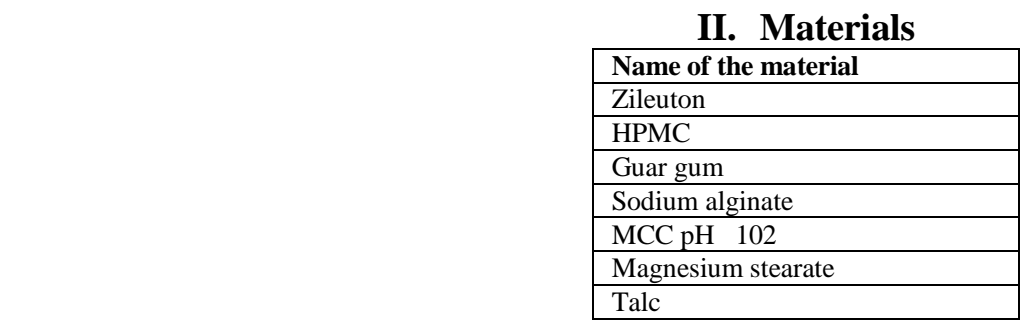




\subsection{Analytical Method Development}

\section{Methodology}

\subsubsection{Determination Of Absorption Maxima}

A solution containing the concentration $10 \mu \mathrm{g} / \mathrm{ml}$ drug was prepared in $0.1 \mathrm{~N} \mathrm{HCl}$ and $\mathrm{pH} 6.8$ Phosphate buffer UV spectrums was taken using Double beam UV/VIS spectrophotometer. The solution was scanned in the range of $200-400$

\subsubsection{Preparation Calibration Curve}

$100 \mathrm{mg}$ of Zileuton pure drug was dissolved in 100ml of Methanol (stock solution)10ml of above solution was taken and make up with $100 \mathrm{ml}$ by using $0.1 \mathrm{~N} \mathrm{HCl}(100 \mu \mathrm{g} / \mathrm{ml})$. From this $10 \mathrm{ml}$ was taken and make up with $100 \mathrm{ml}$ of $0.1 \mathrm{~N} \mathrm{HCl}(10 \mu \mathrm{g} / \mathrm{ml})$. The above solution was subsequently diluted with $0.1 \mathrm{~N} \mathrm{HCl}$ to obtain series of dilutions Containing 2, 4, 6, 8 and $10 \mu \mathrm{g} / \mathrm{ml}$ of Zileuton per $\mathrm{ml}$ of solution. The absorbance of the above dilutions was measured at $230 \mathrm{~nm}$ by using UV-Spectrophotometer taking $0.1 \mathrm{~N} \mathrm{HCl}$ as blank. Then a graph was plotted by taking Concentration on X-Axis and Absorbance on Y-Axis which gives a straight line Linearity of standard curve was assessed from the square of correlation coefficient $\left(\mathrm{R}^{2}\right)$ which determined by least-square linear regression analysis. The above procedure was repeated by using $\mathrm{pH} 6.8$ phosphate buffer solutions.

\subsection{Drug - Excipient Compatibility Studies \\ Fourier Transform Infrared (Ftir) Spectroscopy}

The physical properties of the physical mixture were compared with those of plain drug. Samples was mixed thoroughly with $100 \mathrm{mg}$ potassium bromide IR powder and compacted under vacuum at a pressure of about 12 psi for 3 minutes. The resultant disc was mounted in a suitable holder in Perkin Elmer IR spectrophotometer and the IR spectrum was recorded from $4000 \mathrm{~cm}$ to $500 \mathrm{~cm}$. The resultant spectrum was compared for any spectrum changes.

\subsection{Preformulation Parameters}

The quality of tablet, once formulated by rule, is generally dictated by the quality of physicochemical properties of blends. There are many formulations and process variables involved in mixing and all these can affect the characteristics of blends produced. The various characteristics of blends tested as per Pharmacopoeia.

\section{Angle of Repose}

The frictional force in a loose powder can be measured by the angle of repose. It is defined as, the maximum angle possible between the surface of the pile of the powder and the horizontal plane. The angle of repose was calculated using the following formula;

$\operatorname{Tan} \theta=\mathrm{h} / \mathrm{r}$

Tan $\theta=$ Angle of repose

$\mathrm{h}=$ Height of the cone , $\mathrm{r}=$ Radius of the cone base

\section{Bulk Density}

Density is defined as weight per unit volume. Bulk density, is defined as the mass of the powder divided by the bulk volume and is expressed as $\mathrm{gm} / \mathrm{cm}^{3}$.

The bulk density was calculated using the formula;

Bulk Density $=\mathrm{M} / \mathrm{V}_{\mathrm{o}}$

Where, $M=$ weight of sample

$\mathrm{V}_{\mathrm{o}}=$ apparent volume of powder

\section{Tapped Density}

The cylinder containing the sample was tapped using a suitable mechanical tapped density tester that provides 100 taps per minute and this was repeated until difference between succeeding measurement is less than $2 \%$ and then tapped volume, $\mathrm{V}$ measured, to the nearest graduated unit. The tapped density was calculated, in gm per L, using the formula:

$$
\text { Tap }=\mathrm{M} / \mathrm{V}
$$

Where, Tap $=$ Tapped Density

$\mathrm{M}=$ Weight of sample

$\mathrm{V}=$ Tapped volume of powder 


\section{Measures Of Powder Compressibility}

The compressibility index has been proposed as an indirect measure of bulk density, size and shape, surface area, moisture content and cohesiveness of material because all of these influence the compressibility index. The simple method for measurement of free flow of powder is Carr's Index, a sign of the easiness with which a material can be induced to flow is given by Carr's Index (CI) which is calculated as follows;

$\mathrm{CI}(\%)=[($ Tapped density - Bulk density $) /$ Tapped density $] \mathrm{x} 100$

\section{Hausner Ratio}

Hausner ratio is an indirect index of ease of powder flow. It is calculated by the following formula.

Hausner's Ratio=Tapped density / Bulk density

\subsection{Formulation Development Of Tablets}

All the formulations were prepared by direct compression. The compositions of different formulations are given in Table 6.3.The tablets were prepared as per the procedure given below and aim is to prolong the release of Zileuton. Total weight of the tablet was considered as $800 \mathrm{mg}$.

\section{Procedure}

1) Zileuton and all other ingredients were individually passed through sieve no $\neq 60$.

2) All the ingredients were mixed thoroughly by triturating up to $15 \mathrm{~min}$.

3) The powder mixture was lubricated with talc.

4) The tablets were prepared by using direct compression method.

TABLE 1: Formulation composition for tablets

\begin{tabular}{|c|c|c|c|c|c|c|c|}
\hline $\begin{array}{l}\text { Formulation } \\
\text { No. }\end{array}$ & Zileuton & $\begin{array}{l}\text { Sodium } \\
\text { alginate }\end{array}$ & Guar gum & $\begin{array}{l}\text { HPMC } \\
\text { K15M }\end{array}$ & $\begin{array}{l}\text { Mag. } \\
\text { Stearate }\end{array}$ & Talc & $\begin{array}{l}\text { MCC pH } \\
102\end{array}$ \\
\hline $\mathrm{F} 1$ & 300 & 100 & & & 8 & 8 & 384 \\
\hline F2 & 300 & 200 & & & 8 & 8 & 284 \\
\hline F3 & 300 & 300 & & & 8 & 8 & 184 \\
\hline $\mathrm{F} 4$ & 300 & & 100 & & 8 & 8 & 384 \\
\hline F5 & 300 & & 200 & & 8 & 8 & 284 \\
\hline F6 & 300 & & 300 & & 8 & 8 & 184 \\
\hline F7 & 300 & & & 100 & 8 & 8 & 384 \\
\hline F8 & 300 & & & 200 & 8 & 8 & 284 \\
\hline F9 & 300 & & & 300 & 8 & 8 & 184 \\
\hline
\end{tabular}

All the quantities were in $\mathrm{mg}$

\subsection{Evaluation Of Post Compression Parameters For Prepared Tablets}

The designed formulation tablets were studied for their physicochemical properties like weight variation, hardness, thickness, friability and drug content.

\section{Weight Variation Test}

To study the weight variation, twenty tablets were taken and their weight was determined individually and collectively on a digital weighing balance. The average weight of one tablet was determined from the collective weight. The weight variation test would be a satisfactory method of deter mining the drug content uniformity. Not more than two of the individual weights deviate from the average weight by more than the percentage shown in the following table and none deviate by more than twice the percentage. The mean and deviation were determined. The percent deviation was calculated using the following formula.

$\%$ Deviation $=($ Individual weight - Average weight $/$ Average weight $) \times 100$

\section{Hardness}

Hardness of tablet is defined as the force applied across the diameter of the tablet in order to break the tablet. The resistance of the tablet to chipping, abrasion or breakage under condition of storage transformation and handling before usage depends on its hardness. For each formulation, the hardness of three tablets was determined using Monsanto hardness tester and the average is calculated and presented with deviation.

\section{Thickness}

Tablet thickness is an important characteristic in reproducing appearance. Tablet thickness is an important characteristic in reproducing appearance. Average thickness for core and coated tablets is calculated and presented with deviation. 


\section{Friability}

It is measured of mechanical strength of tablets. Roche friabilator was used to determine the friability by following procedure. Preweighed tablets were placed in the friabilator. The tablets were rotated at $25 \mathrm{rpm}$ for 4 minutes (100 rotations). At the end of test, the tablets were re weighed, loss in the weight of tablet is the measure of friability and is expressed in percentage as

$\%$ Friability $=[(\mathrm{W} 1-\mathrm{W} 2) / \mathrm{W}] \times 100$

Where, $\mathrm{W} 1=$ Initial weight of three tablets

$\mathrm{W} 2=\mathrm{Weight}$ of the three tablets after testing

\subsection{Determination Of Drug Content}

Tablets were tested for their drug content. Ten tablets were finely powdered quantities of the powder equivalent to one tablet weight of drug were accurately weighed, transferred to a $100 \mathrm{ml}$ volumetric flask containing $50 \mathrm{ml}$ media and were allowed to stand to ensure complete solubility of the drug. The mixture was made up to volume with media. The solution was suitably diluted and the absorption was determined by UV Visible spectrophotometer. The drug concentration was calculated from the calibration curve.

\section{In Vitro Drug Release Studies} Dissolution Parameters

$\begin{array}{lll}\text { Apparatus } & -- & \text { USP-II, Paddle Method } \\ \text { Dissolution Medium } & -- & 0.1 \mathrm{~N} \mathrm{HCl}, \mathrm{p} \mathrm{H} 6.8 \text { Phophate buffer } \\ \text { RPM } & -- & 50 \\ \text { Sampling intervals (hrs) } & -- & 0.5,1,2,3,4,5,6,7,8,10,11,12 \\ \text { Temperature } & -- & 37^{\circ} \mathrm{c} \pm 0.5^{\circ} \mathrm{c}\end{array}$

\section{Procedure}

Drug release from formulated controlled tablets was determined by using USP dissolution test apparatus II (Paddle apparatus). The tablets were place in $900 \mathrm{ml}$ of dissolution medium as $\mathrm{pH} 1.2(0.1 \mathrm{~N} \mathrm{HCl})$ for 2 hours then replace the gastric fluid with $\mathrm{pH} 6.8$ phosphate buffer maintained at $37 \pm 0.5{ }^{\circ} \mathrm{C}$ and $50 \mathrm{rpm}$. At appropriate intervals $(0.5,1,2,3,4,5,6,7,8,9,10,11$ and 12 hours) $5 \mathrm{ml}$ of the samples were taken and the dissolution media was then replaced by $5 \mathrm{ml}$ of fresh dissolution fluid to maintain a constant volume. After proper dilution, the samples were then analyzed at $230 \mathrm{~nm}$ by UV-spectrophotometer. The concentration was calculated by using calibration curve.

\subsection{Application Of Release Rate Kinetics To Dissolution Data}

Various models were tested for explaining the kinetics of drug release. To analyze the mechanism of the drug release rate kinetics of the dosage form, the obtained data were fitted into zero-order, first order, Higuchi, and Korsmeyer-Peppas release model.

\section{Zero Order Release Rate Kinetics}

To study the zero-order release kinetics the release rate data ar e fitted to the following equation. $\mathrm{F}=\mathrm{K}_{\mathrm{o}} \mathrm{t}$

Where, ' $F$ ' is the drug release at time' $t$ ', and ' $\mathrm{K}_{\mathrm{o}}$ ' is the zero order release rate constant. The plot of $\%$ drug release versus time is linear.

First Order Release Rate Kinetics

The release rate data are fitted to the following equation $\log (100-\mathrm{F})=\mathrm{kt}$

A plot of log cumulative percent of drug remaining to be released vs. time is plotted then it gives first order release.

\section{Higuchi Release Model}

To study the Higuchi release kinetics, the release rate data were fitted to the following equation.

$$
\mathrm{F}=\mathrm{k} \mathrm{t} 1 / 2
$$

Where, ' $\mathrm{k}$ ' is the Higuchi constant.

In higuchi model, a plot of \% drug release versus square root of time is linear.

\section{Korsmeyer And Peppas Release Model}

The mechanism of drug release was evaluated by plotting the log percentage of drug released versus log time according to Korsmeyer- Peppas equation. The exponent ' $n$ ' indicates the mechanism of drug release 
calculated through the slope of the straight Line.

$$
\mathrm{M}_{\mathrm{t}} / \mathrm{M}_{\infty}=\mathrm{K} \mathrm{t}^{\mathrm{n}}
$$

Where, $M_{t} / M_{\infty}$ is fraction of drug released at time ' $t$ ', $k$ represents a constant, and ' $n$ ' is the diffusional exponent, which characterizes the type of release mechanism during the dissolution process.

\section{Hixson-Crowell Release Model}

$\left(100-\mathrm{Q}_{\mathrm{t}}\right)^{1 / 3}=100^{1 / 3}-\mathrm{K}_{\mathrm{HC}} \cdot \mathrm{t}$

Where, $\mathrm{k}$ is the Hixson-Crowell rate constant.

Hixson-Crowell model describes the release of drugs from an insoluble matrix through mainly erosion. (Where there is a change in surface area and diameter of particles or tablets).

\section{Results And Discussion}

The present study was aimed to developing Sustained release tablets of Zileuton using various polymers. All the formulations were evaluated for physicochemical properties and invitro drug release studies.

\subsection{Analytical Method}

Graphs of Zileuton were taken in Simulated Gastric fluid (pH 1.2) and in p H 6.8 phosphate buffer at $238 \mathrm{~nm}$ and $234 \mathrm{~nm}$ respectively.

TABLE 2: Observations for graph of Zileuton in $0.1 \mathrm{~N} \mathrm{HCl}(230 \mathrm{~nm})$

\begin{tabular}{|l|l|}
\hline Conc $[\boldsymbol{\mu g} / \mathbf{l}]$ & Abs \\
\hline 0 & 0 \\
\hline 2 & 0.231 \\
\hline 4 & 0.428 \\
\hline 6 & 0.66 \\
\hline 8 & 0.925 \\
\hline 10 & 1.155 \\
\hline
\end{tabular}

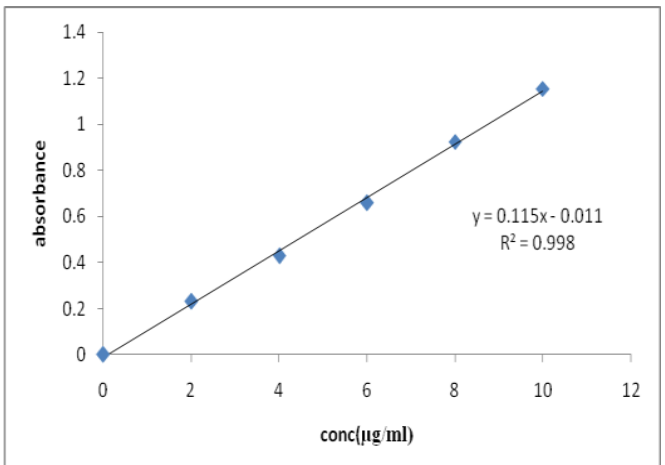

Fig: Standard graph of Zileuton in $0.1 \mathrm{~N} \mathrm{HCl}$

TABLE 3: Observations for graph of Zileuton in p H 6.8 phosphate buffer (229nm)

\begin{tabular}{|l|l|}
\hline Conc $[\boldsymbol{\mu g} / \mathbf{l}]$ & Abs \\
\hline 0 & 0 \\
\hline 2 & 0.157 \\
\hline 4 & 0.299 \\
\hline 6 & 0.411 \\
\hline 8 & 0.57 \\
\hline 10 & 0.71 \\
\hline
\end{tabular}

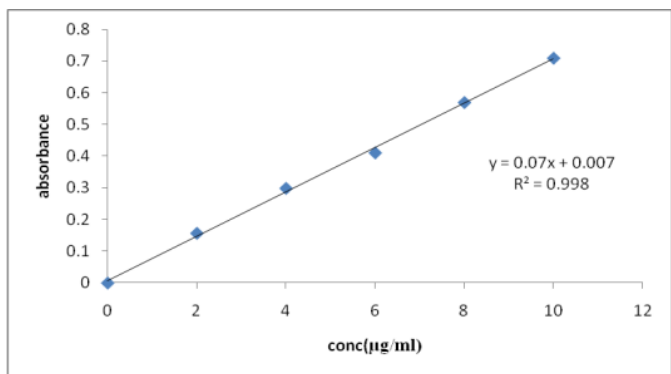

Fig: Standard graph of Zileuton pH 6.8 phosphate buffer $(229 \mathrm{~nm})$ 


\subsection{Drug - Excipient Compatability Studies} Fourier Transform-Infrared Spectroscopy
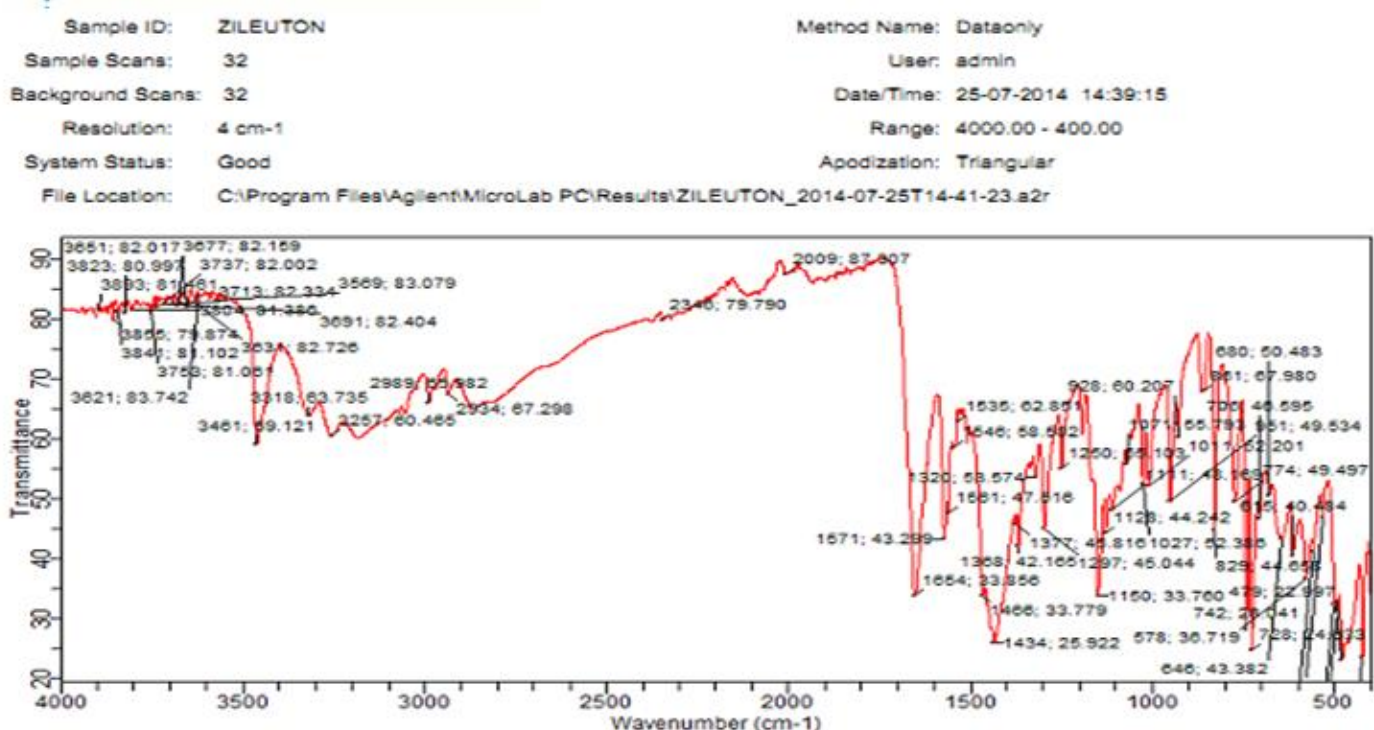

FT-TR Spectrum of Zileuton pure drug

\begin{tabular}{|c|c|c|c|}
\hline Sample ID: & Zileuton & Method Name: & Dataonly \\
\hline Sample Scans: & 32 & User: & admin \\
\hline Background Scans: & 32 & Date/Time: & $11-09-2014 \quad 20: 05: 52$ \\
\hline Resolution: & $4 \mathrm{~cm}-1$ & Range: & $4000.00-400.00$ \\
\hline System Status: & Good & Apodization: & Triangular \\
\hline
\end{tabular}

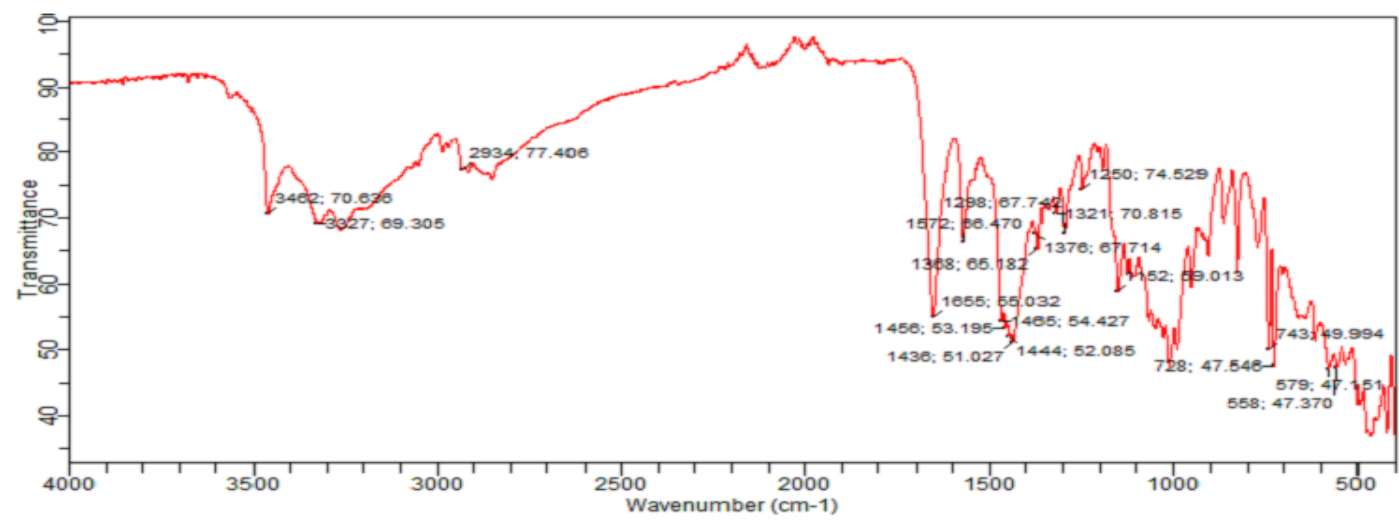

FT-IR Spectrum of Optimised Formulation

\subsection{Preformulation Parameters Of Powder Blend}

TABLE 4: Pre-formulation parameters of Core blend

\begin{tabular}{|c|c|c|c|c|c|}
\hline Formulation Code & Angle of Repose & $\begin{array}{l}\text { Bulk density } \\
(\mathrm{gm} / \mathrm{ml})\end{array}$ & $\begin{array}{l}\text { Tapped density } \\
(\mathrm{gm} / \mathrm{ml})\end{array}$ & Carr's index (\%) & Hausner's Ratio \\
\hline F1 & 26.01 & 0.49 & 0.57 & 14.03 & 1.16 \\
\hline F2 & 24.8 & 0.56 & 0.67 & 16.41 & 1.19 \\
\hline F3 & 22.74 & 0.52 & 0.64 & 18.75 & 1.23 \\
\hline F4 & 25.33 & 0.54 & 0.64 & 15.62 & 1.18 \\
\hline F5 & 26.24 & 0.53 & 0.65 & 18.46 & 1.22 \\
\hline F6 & 26.12 & 0.56 & 0.66 & 15.15 & 1.17 \\
\hline F7 & 27.08 & 0.58 & 0.69 & 15.94 & 1.18 \\
\hline F8 & 25.12 & 0.48 & 0.57 & 15.78 & 1.18 \\
\hline F9 & 25.45 & 0.54 & 0.65 & 16.92 & 1.2 \\
\hline
\end{tabular}




\subsection{Quality Control Parameters For Tablets}

TABLE 5: Invitro quality control parameters for tablets

\begin{tabular}{|l|l|l|l|l|l|}
\hline \multirow{2}{*}{$\begin{array}{l}\text { Formulation } \\
\text { codes }\end{array}$} & $\begin{array}{l}\text { Weight } \\
\text { variation(mg) }\end{array}$ & Hardness(kg/cm2) & $\begin{array}{l}\text { Friability } \\
(\%) \text { loss) }\end{array}$ & $\begin{array}{l}\text { Thickness } \\
(\mathbf{m m})\end{array}$ & $\begin{array}{l}\text { Drug content } \\
(\%)\end{array}$ \\
\hline F1 & 812.5 & 4.5 & 0.50 & 3.8 & 99.76 \\
\hline F2 & 805.4 & 4.5 & 0.51 & 3.9 & 98.45 \\
\hline F3 & 818.6 & 4.4 & 0.51 & 3.9 & 99.34 \\
\hline F4 & 810.6 & 4.5 & 0.55 & 3.9 & 97.87 \\
\hline F5 & 809.4 & 4.4 & 0.56 & 3.7 & 99.14 \\
\hline F6 & 810.7 & 4.5 & 0.45 & 3.7 & 98.56 \\
\hline F7 & 802.3 & 4.5 & 0.51 & 3.4 & 98.42 \\
\hline F8 & 801.2 & 4.3 & 0.49 & 3.7 & 99.65 \\
\hline F9 & 798.3 & 4.5 & 0.55 & 3.6 & 98.12 \\
\hline
\end{tabular}

\subsection{In-Vitro Drug Release Studies}

TABLE 6: Dissolution Data of Zileuton Tablets Prepared With Sodium alginate In Different Concentrations

\begin{tabular}{|l|l|l|l|}
\hline \multirow{2}{*}{$\begin{array}{l}\text { TIME } \\
(\mathbf{h r})\end{array}$} & CUMULATIVE PERCENT DRUG DISSOLVED & \multicolumn{1}{l|}{} \\
\cline { 2 - 4 } $\mathbf{0}$ & F1 & F & 0 \\
\hline $\mathbf{0 . 5}$ & 0 & 20.17 & 16.45 \\
\hline $\mathbf{1}$ & 27.51 & 39.45 & 26.73 \\
\hline $\mathbf{2}$ & 48.74 & 55.33 & 34.64 \\
\hline $\mathbf{3}$ & 74.53 & 75.32 & 42.45 \\
\hline $\mathbf{4}$ & 99.48 & 87.35 & 55.43 \\
\hline $\mathbf{5}$ & & 99.44 & 67.48 \\
\hline $\mathbf{6}$ & & & 85.43 \\
\hline $\mathbf{7}$ & & & 91.55 \\
\hline $\mathbf{8}$ & & & 97.37 \\
\hline
\end{tabular}

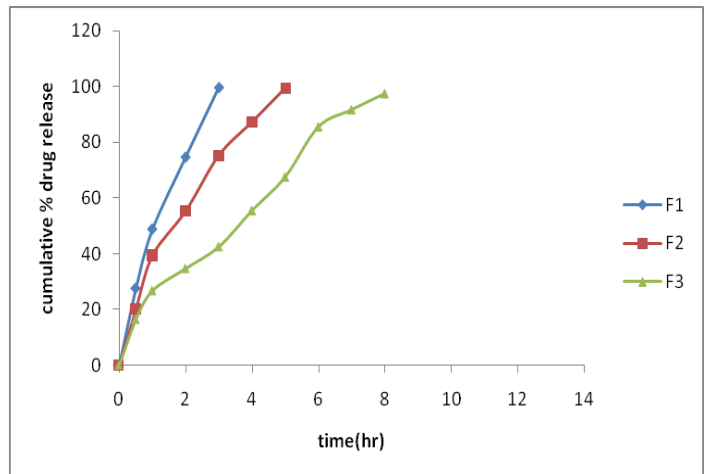

Fig : Dissolution profile of Zileuton (F1, F2, F3 formulations).

TABLE 7: Dissolution Data of Zileuton Tablets Prepared With Guar gum In Different Concentrations

\begin{tabular}{|l|l|l|l|}
\hline \multirow{2}{*}{ TIME } & \multicolumn{2}{|c|}{ CUMULATIVE PERCENT DRUG DISSOLVED } \\
\cline { 2 - 4 } & \multicolumn{2}{|c|}{ F4 F5 } & \multicolumn{1}{c|}{ F6 } \\
\hline $\mathbf{0 . 5}$ & 17.25 & 14.42 & 12.62 \\
\hline $\mathbf{1}$ & 38.26 & 23.73 & 19.86 \\
\hline $\mathbf{2}$ & 56.16 & 36.63 & 23.35 \\
\hline $\mathbf{3}$ & 72.01 & 45.04 & 30.45 \\
\hline $\mathbf{4}$ & 85.26 & 58.25 & 39.80 \\
\hline $\mathbf{5}$ & 97.10 & 65.33 & 45.25 \\
\hline $\mathbf{6}$ & & 76.41 & 53.24 \\
\hline $\mathbf{7}$ & & 84.84 & 61.73 \\
\hline $\mathbf{8}$ & & 97.80 & 69.34 \\
\hline $\mathbf{9}$ & & & 75.52 \\
\hline $\mathbf{1 0}$ & & & 82.17 \\
\hline $\mathbf{1 1}$ & & & 89.10 \\
\hline $\mathbf{1 2}$ & & & 98.86 \\
\hline
\end{tabular}




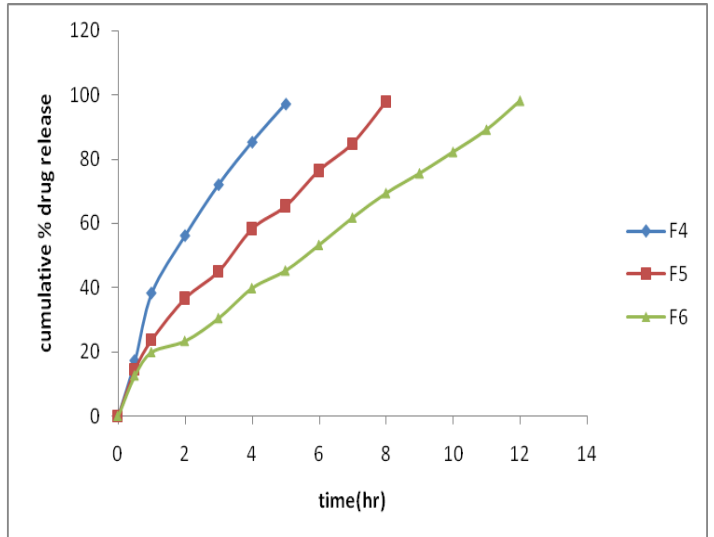

Fig7.6: Dissolution profile of Zileuton (F4, F5, F6 formulations)

TABLE 8: Dissolution Data of Zileuton Tablets Prepared With HPMC K15M In Different Concentrations

\begin{tabular}{|l|l|l|l|}
\hline \multirow{2}{*}{$\begin{array}{c}\text { TIME } \\
(\mathbf{h r})\end{array}$} & \multicolumn{1}{|c|}{ CUMULATIVE PERCENT DRUG DISSOLVED } & \multicolumn{1}{c|}{ F9 } \\
\cline { 2 - 4 } $\mathbf{0 . 5}$ & 14.4 & 11.4 & 8.5 \\
\hline $\mathbf{1}$ & 18.5 & 17.6 & 14.5 \\
\hline $\mathbf{2}$ & 26.6 & 23.4 & 18.4 \\
\hline $\mathbf{3}$ & 32.5 & 30.7 & 23.4 \\
\hline $\mathbf{4}$ & 44.5 & 38.4 & 28.2 \\
\hline $\mathbf{5}$ & 50.4 & 44.6 & 34.8 \\
\hline $\mathbf{6}$ & 67.2 & 52.3 & 40.2 \\
\hline $\mathbf{7}$ & 76.5 & 61.3 & 44.8 \\
\hline $\mathbf{8}$ & 88.3 & 70.8 & 50.4 \\
\hline $\mathbf{9}$ & 97.78 & 79.52 & 63.34 \\
\hline $\mathbf{1 0}$ & & 86.65 & 69.27 \\
\hline $\mathbf{1 1}$ & & 97.56 & 74.86 \\
\hline $\mathbf{1 2}$ & & & 82.97 \\
\hline
\end{tabular}

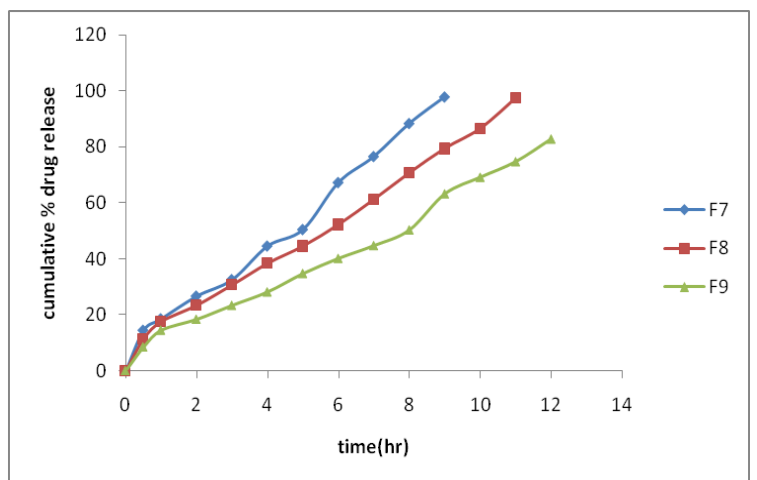

Fig : Dissolution profile of Zileuton (F7, F8, F9 formulations)

From the dissolution data it was evident that the formulations prepared with Sodium alginate as polymer were unable to retard the drug release up to desired time period i.e., 12 hours.

Whereas the formulations prepared with Guar gum retarded the drug release in the concentration of 300 mg (F6 Formulation ) showed required release pattern i.e., retarded the drug release up to 12 hours and showed maximum of $98.86 \%$ in 12 hours with good retardation.

The formulations prepared with HPMC K15M showed more retardation even after 12 hours they were not shown total drug release. Hence they were not considered.

\section{Application Of Release Rate Kinetics To Dissolution Data}

Various models were tested for explaining the kinetics of drug release. To analyze the mechanism of the drug release rate kinetics of the dosage form, the obtained data were fitted into zero-order, first order, Higuchi, and Korsmeyer-Peppas release model. 
TABLE 9: Release kinetics data for optimised formulation

\begin{tabular}{|c|c|c|c|c|c|c|c|c|c|}
\hline $\begin{array}{l}\text { CUMULATIV } \\
\text { E } \quad(\%) \\
\text { RELEASE } \mathbf{Q}\end{array}$ & $\begin{array}{l}\text { TIM } \\
\text { E }( \\
\text { T })\end{array}$ & $\begin{array}{l}\text { ROO } \\
\text { T } \quad( \\
\text { T) }\end{array}$ & $\begin{array}{l}\text { LOG( \%) } \\
\text { RELEASE }\end{array}$ & $\begin{array}{l}\text { LOG ( } \\
\text { T ) }\end{array}$ & $\begin{array}{l}\text { LOG (\%) } \\
\text { REMAIN }\end{array}$ & $\begin{array}{l}\text { ELEASE RATE } \\
\text { (CUMULATIVE \% } \\
\text { RELEASE / t) }\end{array}$ & $\begin{array}{l}\text { 1/CUM } \\
\% \\
\text { RELEA } \\
\text { SE }\end{array}$ & $\begin{array}{l}\text { PEPPA } \\
\text { S log } \\
Q / 100\end{array}$ & $\begin{array}{l}\text { \% Drug } \\
\text { Remaini } \\
\text { ng }\end{array}$ \\
\hline 0 & 0 & 0 & & & 2.000 & & & & 100 \\
\hline 12.62 & 0.5 & 0.707 & 1.101 & -0.301 & 1.941 & 25.240 & 0.0792 & -0.899 & 87.38 \\
\hline 19.86 & 1 & 1.000 & 1.298 & 0.000 & 1.904 & 19.860 & 0.0504 & -0.702 & 80.14 \\
\hline 23.35 & 2 & 1.414 & 1.368 & 0.301 & 1.885 & 11.675 & 0.0428 & -0.632 & 76.65 \\
\hline 30.45 & 3 & 1.732 & 1.484 & 0.477 & 1.842 & 10.150 & 0.0328 & -0.516 & 69.55 \\
\hline 39.8 & 4 & 2.000 & 1.600 & 0.602 & 1.780 & 9.950 & 0.0251 & -0.400 & 60.2 \\
\hline 45.25 & 5 & 2.236 & 1.656 & 0.699 & 1.738 & 9.050 & 0.0221 & -0.344 & 54.75 \\
\hline 53.24 & 6 & 2.449 & 1.726 & 0.778 & 1.670 & 8.873 & 0.0188 & -0.274 & 46.76 \\
\hline 61.73 & 7 & 2.646 & 1.790 & 0.845 & 1.583 & 8.819 & 0.0162 & -0.210 & 38.27 \\
\hline 69.34 & 8 & 2.828 & 1.841 & 0.903 & 1.487 & 8.668 & 0.0144 & -0.159 & 30.66 \\
\hline 75.52 & 9 & 3.000 & 1.878 & 0.954 & 1.389 & 8.391 & 0.0132 & -0.122 & 24.48 \\
\hline 82.17 & 10 & 3.162 & 1.915 & 1.000 & 1.251 & 8.217 & 0.0122 & -0.085 & 17.83 \\
\hline 89.1 & 11 & 3.317 & 1.950 & 1.041 & 1.037 & 8.100 & 0.0112 & -0.050 & 10.9 \\
\hline 98.86 & 12 & 3.464 & 1.995 & 1.079 & 0.057 & 8.238 & 0.0101 & -0.005 & 1.14 \\
\hline
\end{tabular}

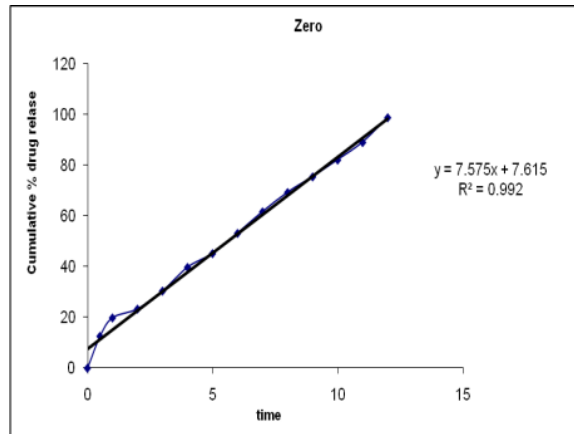

Fig : Zero order release kinetics graph

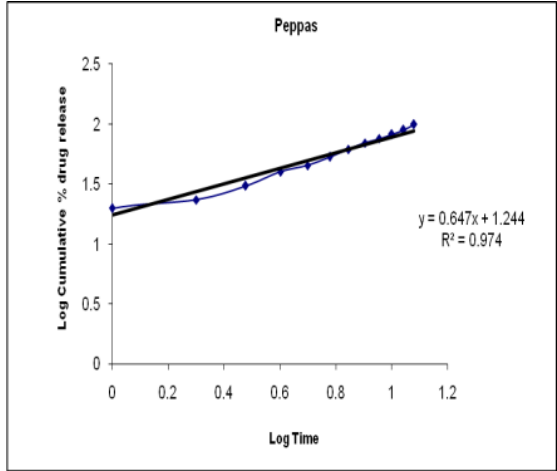

Fig: Kars mayer peppas graph

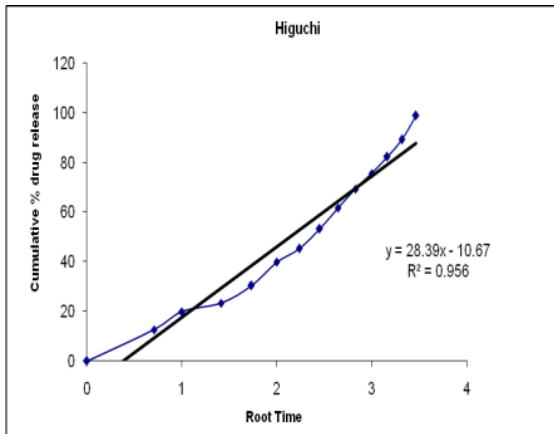

Fig : Higuchi release kinetics graph

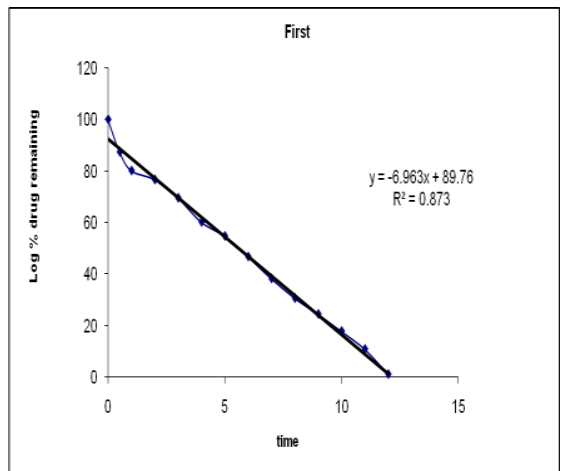

Fig : First order release kinetics graph

From the above graphs it was evident that the formulation F6 was followed Zero order release kinetics.

\section{Conclusion}

The aim of the present study was to develop Controlled release formulation of Zileuton to maintain constant therapeutic levels of the drug for over 12 hrs. sodium alginate, guar gum and HPMC K15M were employed as polymers. Zileuton dose was fixed as $300 \mathrm{mg}$. Polymers were used in the concentration of 100, 200 and $300 \mathrm{mg}$ concentration. All the formulations were passed various physicochemical evaluation parameters and they were found to be within limits. Whereas from the dissolution studies it was evident that the formulation (F6) showed better and desired drug release pattern i.e., $98.86 \%$ in 12 hours. It contains the natural polymer Zileuton as controlled release material. It followed zero order release kinetics mechanism. 


\section{Bibliography}

[1]. 1Nokhodchi, Shaista Raja, Priya Patel, Kofi Asare-Addo. The Role Of Oral Controlled Release Matrix Tablets In Drug Delivery Systems. Bioimpacts. 2(4);175-187:2012.

[2]. 39Amir Badshah, FazalSubhan, Khalid Rauf, Nadeem Irfan Bukhari, Zia Ahmed. Development Of Controlled-Release Matrix Tablet Of Resperidone: Influence OfMethocel®-And Ethocel®-Based Novel Polymeric Blend On In-Vitro Drug Release And Bioavailability. AAPS Pharm. sci.tech. 12(2);525-533:2011

[3]. Anil K. Anal. Time-Controlled Pulsatile Delivery Systems For Bioactive Compounds. Recent Patents On Drug Delivery \& Formulation. 1;73-79:2007.

[4]. Anne B Chang, John G Widdicombe. Cough throughout life: children, adults and the senile. Pulmonary Pharmacology \& Therapeutics. 20;371-382:2007.

[5]. Ansel HC, Allen LV, Popvich NG. Pharmaceutical Dosage Forms And Drug Delivery System. 2000; $7^{\text {th }}: 229-243$

[6]. [6] 2Aravind Singh Rathore, Jat RC, Narendra Sharma, Rahul Tiwari. An Overview: Matrix Tablet As Controlled Drug Delivery System. International Journal Of Research And Develoment In Pharmacy And Lisfe Sciences. 2(4);482-492:2013.

[7]. 31Ashtamkar Joel, Nangude Shantaramand Chugh Naresh. Formulation And Evaluation Of Controlled Release Tablets Of Labetalol Hydrochloride Using Hydrophobic Polymers. International Journal Of Research in Pharmaceutical And Biomedical Sciences. 4(1);380-384:2013.

[8]. Avgoustakis K, Nixon JR. Biodegradable Controlled Release Tablets: Effect Of Polymer Characteristics On Drug Release From Heterogeneous Poly (Lactide-co-Glycolide) Matrices. Int. J. Pharm. 99;247-252:1993.

[9]. Bala Ramesha Chary R, Madhusudan Rao Y. Formulation And Evaluation Of Methocel K15M Bioadhesive Matrix Tablets. Drug Development And Industrial Pharmacy. 26(8);901-906:2000.

[10]. 26Banker GS, Rhodes CT. Modern Pharmaceutics. Sustained and Controlled Release Delivery Systems. Marcel Dekker. 2002; $4^{\text {th }}$ :501-528.

[11]. 3Bhalla Neetika, Deep Arsh, Goswami Manish. An Overview On Various Approaches To Oral Controlled Drug Delivery System Via Gastoretentive Drug Delivery System. Int. Res. J. Pharm.3(4);128-133:2012.

[12]. Bonny JD, Leuenberger H. Matrix Type Controlled Release Systems: Effect Of Percolation On Drug Dissolution Kinetics. Pharm. Acta. Helv. 66(5-6);160-164:1991.

[13]. 19Borguist P, Korner A, Larsson A. A model for the drug release from a polymeric matrix tablets-effect of swelling and dissolution. J Control Release. 113;216-225:2006.

[14]. 7Bramhanker DM, Jaiswal SB. Controlled Release Medications. Biopharmaceutics And Pharmacokinetics a Treatise. Vallabh Prakashan, $1995 ; 2^{\text {nd }}: 335-375$.

[15]. 53Catena E, Dafton Chio. Efficasy And Tolerability Of Levodropropizine In Adult Patients With Non Productive Cough: Comparision With Dextromethorphan. Pulmonary Pharmacology And Therapeutics.10;89-96:1997.

[16]. Chang KT, Coffin MD, McGinity JW. Properties Of Controlled Release Matrix

[17]. Tablets Containing DL- Polylactic acid as the Retardant Polymer. J. Pharm. Sci. 76(11);259:1987.

[18]. 35Charulatha R, Kumaravel Rajan R. Design And Evaluation Of Carbamazepine Controlled Release Drug Delivery System. International Journal Of Pharm Tech Research. 4(1):25-34;2012.

[19]. Chidambaram N, Porter W, Flood K, Qiu Y. Formulation And Characterization Of New Layered Diffusional Matrices For ZeroOrder Sustained Release. 52(1-2);149-158:1998.

[20]. 13Chien YW, Controlled Drug Delivery Systems. Novel Drug Delivery Systems, Marcel Dekker, $1992 ; 2^{\text {nd }}: 139-196$.

[21]. 41Chitta Suresh Kumar, Pilli Yesupadam, Harika B, Deepika D, Chandra Sekhar A. Formulation And Evaluation Of Once-Daily Sustained Release Aceclofenac ProsophisJuliflora Gum Matrix Tablets. International Journal Of Pharmaceutical Sciences Review And Research. 1(2);23-27:2010.

[22]. 25Christian Nordqvist. Cough and Causes of cough. 6;1-3:2011.

[23]. Chung KF, Pavord ID.Cough, en.wikipedia.org. 1;1-7:2013.

[24]. 24Collett J, Morenton C. Pharmaceutics: The Science And Practice Of Pharmacy. Churchill livingstone. 2002;2 ${ }^{\text {nd }: ~ 295-299 . ~}$

[25]. Colombo P. Swelling Controlled Release In Hydrogel Matrices For Oral Route. Adv. Drug Del. Rev. 11;37-57:1993. 